\title{
Perancangan Kampanye Wisata Kawasan Riung, Flores, NTT Untuk Wisatawan Asing
}

\author{
Gisela Anindita \\ Pascasarjana Institut Seni Indonesia Yogyakarta \\ gisellaaninditaa@gmail.com
}

\begin{abstract}
ARTICLE INFO
ABSTRACT

Article history:

Indonesia has extraordinary natural beauty. The natural beauty

Received: 22 Mei 2018

with a mixture of tropical climate makes Indonesia has its own

Revised: 10 September

2018

exotic expression in the eyes of foreign tourists. Unfortunately, only a few natural attractions that are considered by foreign tourists, and

Accepted: 1 November these places are increasingly crowded and not considered the 2018 preservation of nature. This campaign offers a new natural tourist destination in the eastern part of Indonesia, namely an area on the

Keywords: island of Flores called Riung. A coastal coastal area that is calm

Tourism campaign and still maintained by its natural beauty. By applying the concept

Riung of Ecotourism, this campaign invites foreign tourists to mingle with

Flores the lives of the peaceful Riung people while enjoying the exotic natural beauty of Riung.
\end{abstract}

\section{PENDAHULUAN}

Kini banyak dari tempat-tempat wisata di Indonesia yang telah kehilangan keaslian alam dan kebudayaannya. Sedangkan, masih banyak wisatawan yang mencari tempat wisata yang masih asli, alami, terjaga ekosistem alam, maupun identitas budaya nya. Karena itu, bagi beberapa wisatawan asing yang mencari ketenangan, mereka rela mengeluarkan budget besar untuk menjelajahi wilayah-wilayah di Indonesia yang masih belum terjamah oleh kehidupan modern. Yang mereka cari hanyalah keramahan orang lokal dan keindahan alam yang masih perawan.

Seperti hal nya daerah Riung, NTT. Kawasan pantai yang memiliki 17 pulau ini merupakan salah satu tujuan beberapa wisatawan asing. Dengan kesederhanaan nya dan keindahan alamnya, banyak wisatawan asing yang lebih memilih datang ke tempat ini. Walaupun belum ada hotel berbintang di tempat ini, mereka justru sangat menikmati penginapan lokal yang dikelola oleh warga. Restoran pun tidak ada di daerah ini. Hanya ada beberapa rumah makan sederhana yang menyajikan makanan khas daerah dan beberapa makanan western seadanya. 
Dengan melihat potensi dari daerah Riung ini, maka disusun lah rancangan campaign ini untuk mempromosikan keindahan wisata alam Riung, NTT yang mengusung konsep kesederhanaan. Ini selaras dengan program Bupati Kabupaten Ngada, Marianus Sae untuk mempromosikan Riung sebagai salah satu tempat wisata alam laut yang menerapkan konsep Ecotourism di Kabupaten Ngada, NTT. Beliau dan masyarakat Riung sepakat untuk tidak menyerahkan pengelolaan wisata daerah Riung kepada orang lain, misalnya pihak swasta. Semua dikelola oleh masyarakat sekitar. Ini semua demi terjaganya keindahan alam dan kedamaian kehidupan di daerah tersebut. Karena mereka menganggap bahwa jika pihak dari luar ikut serta mengelola daerah ini, maka kekayaan alam mereka akan rusak karena dieksploitasi. Tetapi mereka tidak menutup diri kepada wisatawan dalam negeri maupun luar negeri untuk datang melihat keindahan alam daerah Riung.

\section{METODE PERANCANGAN}

Metode yang digunakan adalah kualitatif dengan teknik pengumpulan data yang digunakan adalah wawancara dan observasi etnografis. Penulis melakukan observasi selama 1 bulan di daerah Riung. Responden yang diwawancarai oleh penulis adalah Bupati Kabupaten Ngada, 10 masyarakat Riung, dan 10 wisatawan asing yang ada di Riung. Perancangan yang dilakukan penulis dilakukan berdasarkan dua teori, yakni mengenai marketing dan pariwisata.

\section{PEMBAHASAN}

\subsection{Landasan Teori Destination Market Strategi}

Red oceans mewakili semua industri yang ada pada saat ini - pada market yang ada. Red Oceans memiliki persaingan yang sangat kompetitif dari semua jenis produk. Setiap produk mencoba tampil semenarik mungkin untuk mengalahkan saingannya dan menjadi produk nomor satu dalam penjualan. Setiap harinya market menjadi semakin ramai, dan prospek untuk menarik keuntungan dan berkembang menjadi semakin sulit. Produk semakin memfokuskan target market dan persaingan berubah menjadi tidak sehat sehingga merubah Red Oceans menjadi Bloody Oceans.

Blue oceans, sangat kontras dengan industri yang belum ada saat ini - market yang belum diketahui, jauh dari persaingan. Di Blue Oceans, kebutuhan konsumer diciptakan lebih dari permintaan yang ada. Produk pada Blue Oceans menawarkan market baru. Blue Oceans adalah analogi dari market yang lebih luas, dan lebih dalam yang belum di eksplor. 


\subsection{Landasan Teori Ecotoursim}

Ekowisata atau ekoturisme merupakan salah satu kegiatan pariwisata yang berwawasan lingkungan dengan mengutamakan aspek konservasi alam, aspek pemberdayaan sosial budaya ekonomi masyarakat lokal serta aspek pembelajaran dan pendidikan. Ekowisata dimulai ketika dirasakan adanya dampak negatif pada kegiatan pariwisata konvensional. Dampak negatif ini bukan hanya dikemukakan dan dibuktikan oleh para ahli lingkungan tapi juga para budayawan, tokoh masyarakat dan pelaku bisnis pariwisata itu sendiri. Dampak berupa kerusakan lingkungan, terpengaruhnya budaya lokal secara tidak terkontrol, berkurangnya peran masyarakat setempat dan persaingan bisnis yang mulai mengancam lingkungan, budaya dan ekonomi masyarakat setempat.

\subsection{Ecotourism di Indonesia}

Di Indonesia kegiatan ekowisata mulai dirasakan pada pertengahan 1980-an, dimulai dan dilaksanakan oleh orang atau biro wisata asing, salah satu yang terkenal adalah Mountain Travel Sobek - sebuah biro wisata petualangan tertua dan terbesar. Beberapa objek wisata terkenal yang dijual oleh Sobek antara lain adalah pendakian gunung api aktif tertinggi di garis khatulistiwa Gunung Kerinci (3884 m), pendakian danau vulkanik tertinggi kedua di dunia - Danau Gunung Tujuh dan kunjungan ke danau vulkanik terbesar didunia - Danau Toba. Beberapa biro wisata lain maupun perorangan yang dijalankan oleh orang asing juga melaksanakan kegiatan kunjungan dan hidup bersama suku-suku terasing di Sumatera, Kalimantan, Jawa, Sulawesi dan Papua. Salah satu dari proyek ekowisata yang terkenal yang dikelola pemerintah bersama dengan lembaga asing adalah ekowisata orang hutan di Tanjung Puting, Kalimantan.

Kegiatan ekowisata di Indonesia diatur Peraturan Menteri Dalam Negeri No. 33 Tahun 2009. Secara umum objek kegiatan ekowisata tidak jauh berbeda dari kegiatan wisata alam biasa, namun memiliki nilai-nilai moral dan tanggung jawab yang tinggi terhadap objek wisatanya.

\subsection{Deskripsi Data}

\section{a. Riung}

Riung adalah Kecamatan yang berada di Kabupaten Ngada, Flores NTT. Riung memiliki luas wilayah 327,94 $\mathrm{Km}^{2}$ dengan jumlah penduduk 15.744 jiwa. Riung memiliki beberapa daerah wisata alam, diantaranya Tanjung 15, 17 Pulau, Suaka Alam Terong Padang, dan Teluk Labuan Kelambu. Sebagian besar wilayah Riung terdiri dari padang rumput. Pada bulan Juli hingga November padang rumput tersebut berubah menjadi kering dan gersang, tetapi itu justru menjadi 
pemandangan yang sangat unik dan indah. Tetapi ketika bulan Januari, padang rumput tersebut berubah menjadi hijau dan sangat indah.

Pekerjaan masyarakat Riung pada umumnya adalah petani sawah tadah hujam, nelayan, pemilik penginapan, dan juga beberapa menyewakan kapal dan peralatan snorkeling. Yang lainnya ada yang membuka warung, rumah makan, atau bekerja sebagai pegawai pemerintahan. Mayoritas penduduk Riung beragama Muslim. Tetapi walaupun begitu, masyarakat daerah Riung hidup dalam harmonisasi.

Riung memiliki 4 penginapan. 3 diantaranya adalah hostel. Dan 1 adalah cottage milik warga dari Kota Bajawa, Flores. Ketiga tempat penginapan tersebut cukup untuk menampung kurang lebih 1000 wisatawan setiap tahunnya. Berdasarkan data yang di dapat dari Dinas Pariwisata Daerah Flores, 80\% wisatawan yang datang berasal dari Eropa, dan sekitar 10\% berasal dari Australia. Jumlah tersebut masih dianggap kurang untuk memenuhi keperluan pemasukan daerah, khususnya para warga yang bekerja dalam bidang pariwisata tersebut. Para wisatawan asing biasanya berkunjung ke daerah tersebut sekitar 3-5 hari.

Semua wisatawan yang datang umumnya memilih untuk mengunjungi wisata taman laut 17 pulau untuk diving dan snorkeling. Tidak heran, karena 9 dari 17 pulau dapat kita singgahi untuk beristirahat, snorkeling ataupun diving setelah berkeliling dengan perahu. Satu perahu yang disewakan dihargai dengan sangat murah, sekitar Rp. 500.000 untuk satu perahu yang berisi maksimal 8 orang. Biasanya disarankan untuk mulai berlayar ketika matahari terbit, sehingga kita dapat melihat matahari terbit dari atas perahu dan juga melihat terumbu karang dan ikan-ikan dari atas perahu.

Kedalaman laut di Riung untuk kegiatan snorkeling hanyalah 1 meter. Sehingga aman bagi mereka yang masih belajar snorkeling. Dan juga laut yang tenang menjadikan kita betah untuk melihat keindahan alam lautnya. Yang paling terkenal di Riung adalah terumbu karang berbentuk bunga mawar yang sedang mekar dengan besar diameter mencapai 1 meter. Dan tidak hanya ada 1, tetapi ada 3 terumbu karang seperti ini.

Dan hasil observasi melalui wawancara 10 wisatawan asing yang merupakan target komunikasi kampanye wisata ini menjadi analisa untuk perancangan strategi komunikasi kampanye ini. Wisatawan asing yang menjadi responden seluruhnya berasal dari benua Eropa. Negara asal responden bukan merupakan pemilihan yang direncanakan, melainkan acak dari 37 wisatawan asing yang berada di Riung pada saat penelitian.

\subsection{Strategi Komunikasi}


Penulis menggunakan analisa SWOT untuk merancang strategi komunikasi kampanye dan desain. Melalui analisa SWOT tersebut, hasil yang didapat merupakan kekuatan dari Riung adalah eksotis, natural, dan ekosistem yang terjaga. Kelemahannya adalah Riung hanya dikunjungi pada bulan tertentu, semisal libur musim panas benua Eropa. Sedangkan peluang yang dapat dikembangkan adalah dapat menjadi pilihan lain untuk wisata alam laut di Indonesia. Ancamannya adalah ancaman eksploitasi. Dengan menargetkan campaign ini kepada turis asing, khusunya Eropa dengan usia 40-50 tahun, komunikasi yang dipilih menggunakan bahasa Inggris, yang merupakan bahasa universal.

\section{a. Big Idea}

Big Idea diambil dari ciri khas wilayah Riung yang mempunyai 17 pulau dengan keunggulan yang berbeda-beda dan memakai kata kunci tenang. Maka dibuat Big Idea sebagai,

\section{“HOLY 17 ISLANDS”}

\section{b. Positioning Statement}

Menjadikan campaign ini sebagai media promosi wilayah wisata alam laut, Riung sebagai tujuan wisata laut yang mengusung konsep Ecotourism.

\section{c. Tagline}

"Your Tranquil Experience"

Menjelaskan tentang Brand Identity dari Riung tersebut yang merupakan tempat yang tenang untuk berlibur. Tempat yang berbeda dari tempat wisata lain yang menawarkan kemewahan dan modernitas.

\section{d. Strategi Desain}

Strategi desain yang dipakai adalah mengarah pada gaya desain Jepang yang tenang dan memakai fotografi panoramic yang bertujuan untuk memperlihatkan dan memperkenalkan alam Riung.

\section{e. Pendekatan Rasional dan Emosional}

Dengan menampilkan brand personality yang tenang, dan natural, menimbulkan keinginan target market untuk mengunjungi Riung. Karena secara emosional, target market memiliki kesamaan personality dengan Riung, yaitu ketenangan.

\section{f. Strategi Verbal dan Strategi Visual}

Bahasa yang dipakai adalah bahasa Inggris, sesuai dengan target konsumen campaign ini, yaitu wisatawan asing, khususnya wilayah Eropa. Dan dibantu dengan beberapa bahasa daerah 
Riung. Dan dengan visual pantai dan laut yang biru dipasangkan dengan warna-warna kain daerah Riung.

\section{g. Implementasi Media}

- Logo

Membuat logo wisata alam Riung agar mudah diingat.

\section{- Corporate Branding}

Corporate Branding membantu agar logo dan brand wisata Riung menjadi kuat di mata wisatawan.

\section{- Microsite}

Microsite digunakan untuk menjadi media utama untuk menyampaikan informasi yang lengkap mengenai wisata alam Riung.

\section{- Aplikasi Smartphone}

Aplikasi smartphone berupa augmented reality digunakan untuk menarik wisatawan untuk men'trial' atau mencoba menikmati wisata ruing melalui layar handphone. Aplikasi ini seperti jendela untuk melihat Riung.

\section{- Viral Video}

Viral Video dibuat untuk memberi tahu target konsumen seperti apa suasana di Riung dan juga kegiatan apa saja yang bisa dilakukan di Riung. Viral video disebar melalui Youtube dan Vimeo.

\section{- Booklet}

Booklet dibuat dan diletakan di tempat-tempat agen wisata seperti di Bandara. Isinya berupa foto-foto kegiatan dan suasana di Riung. Dibuat dalam bentuk booklet karena mudah dibawa dan simple.

\section{- Print Ad di Airlines Magazine}

Bekerja sama dengan maskapai penerbangan, seperti Garuda, Batik Air, Air Asia, dll untuk memuat iklan wisata alam Riung di majalah maskapai mereka. Dan beberapa artikel di majalah maskapai tersebut.

\section{- Print Ad di BlueBird Group Magazine}

Bekerja sama dengan taksi Blue Bird Group untuk memuat iklan wisata alam Riung di majalah maskapai mereka. Dan beberapa artikel di majalah maskapai tersebut. Mengapa Blue Bird, karena Blue Bird memiliki Silver Bird yang merupakan taksi yang paling dipercaya dan paling sering dipakai oleh businessman dalam maupun luar negeri.

\section{- Review oleh Travel Blogger}


Bekerja sama dengan beberapa travel blogger terkenal luar negeri untuk berkunjung dan mereview tentang wisata alam Riung.

\section{- E-Banner}

E-Banner diletakan di situs-situs travelling dan penjualan tiket online.

- Flyer

Flyer diletakan di travel agensi

\section{- Postcard}

Bekerja sama dengan beberapa warga di Riung, seperti misalnya penjual kain tenun, ataupun restoran yang ada di sana untuk menjual postcard Riung. Postcard akan di desain semeranik dan seunik mungkin agar bagi para wisatawan yang sedang berlibur di Riung, dapat memamerkan keindahan Riung dengan mengirimkan postcard.

\subsection{Implementasi Desain}

\section{a. Font}

\section{Notera Personal}

$$
\begin{aligned}
& \text { ABCDEFGHLIKLMNODQ } \\
& \text { estuvwxyz } \\
& \text { Abedefghtjklmnapqustwn } \\
& \text { w } x z
\end{aligned}
$$

Font Notera dipilih untuk penggunaan headline karena jenis font handwriting ini merupakan perwakilan dari target konsumen yang masih sering menggunakan handwriting. Sehingga ketika membaca headline dengan jenis tersebut, target market merasa adanya kesamaan sifat dari Brand Personality Riung tersebut.

TW Cen

MT

\section{A B C DEFGHIJKLMNOPQR STUVWXYZ}

$A b c d$ e $f g h l j k I m n \circ p q r s \dagger u$ 
Jenis font ini digunakan dalam penulisan body copy karena memudahkan audience untuk membaca keterangan tentang Riung. Body copy sangat penting untuk memiliki legibility karena di situlah audience mendapatkan penjelasan dan pengenalan mengenai Riung.

\section{b. Color Pallet}

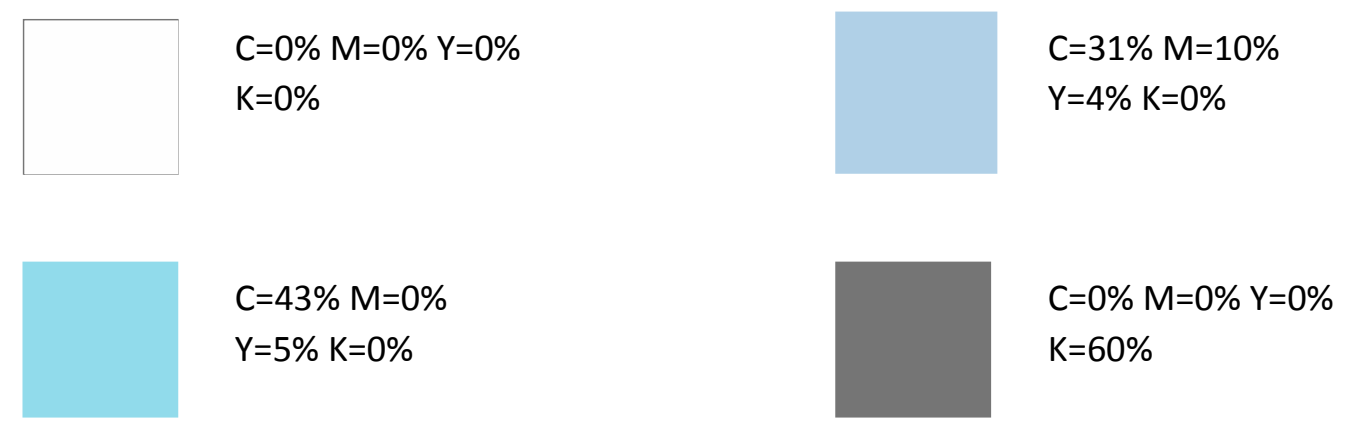

Color Pallet ini dipilih untuk perwakilan warna laut yang merupakan unsur utama dari daerah Riung.

\subsection{Logo}

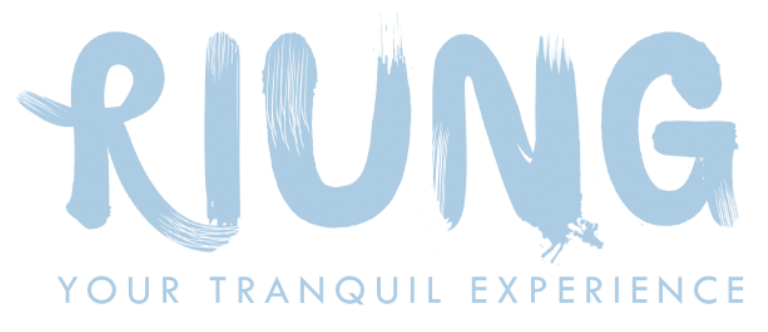

Gambar 1. Logo Riung

Memakai brush agar melihatkan unsur air sebagai perwakilan Riung yang merupakan daerah pantai.

\section{c. Tagline}

\section{"YOUR TRANQUIL EXPERIENCE"}




\section{d. Fotografi}

Campaign ini banyak sekali menggunakan fotografi landscape. Dikarenakan campaign ini bertujuan mengkomunikasikan keindahan alam di daerah Riung ini. Dan juga B\&W foto untuk fotografi di luar landscape.

e. Media

- Website

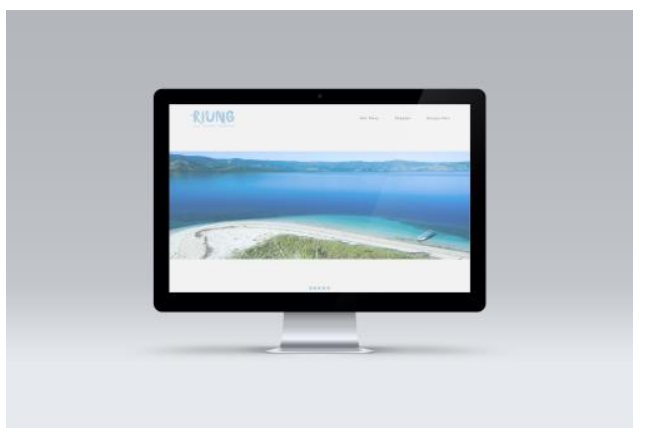

Gambar 2. Tampilan website

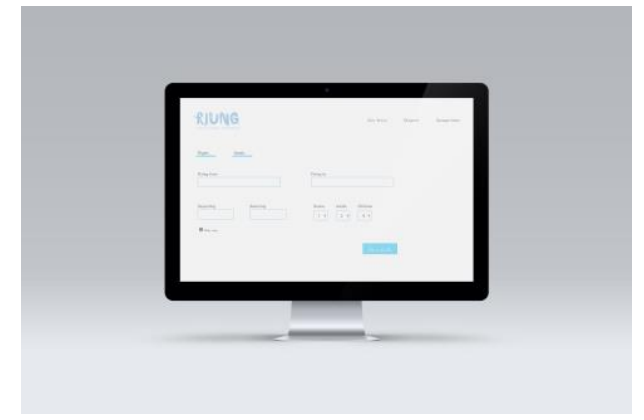

- Booklet

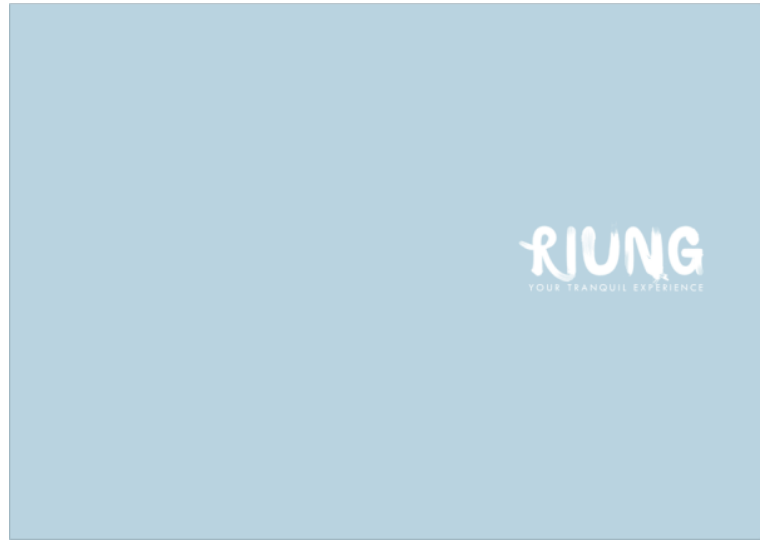

Gambar 3. Tampilan booklet 


\section{- Video Series}
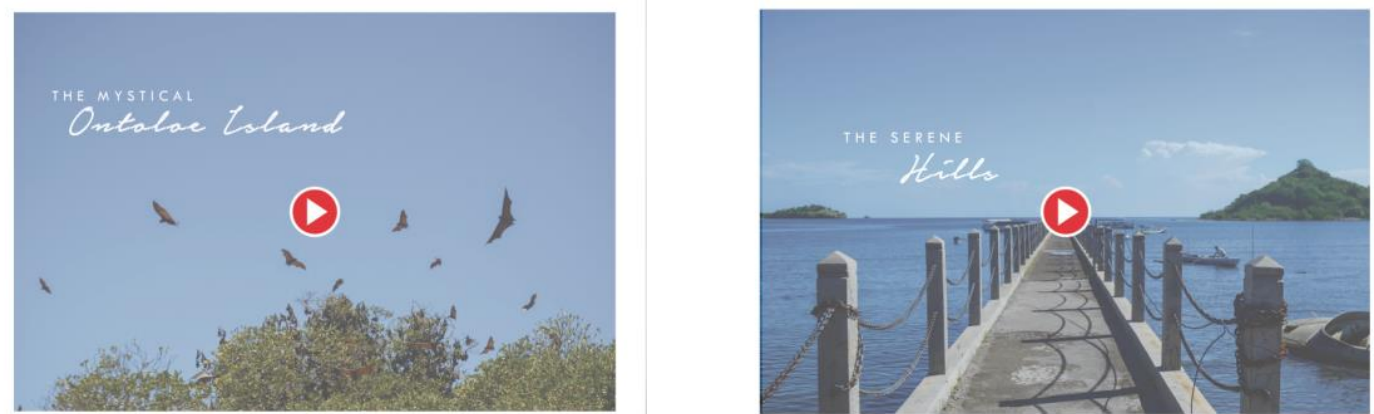

Gambar 4. Tampilan video series

\section{- Billboard}
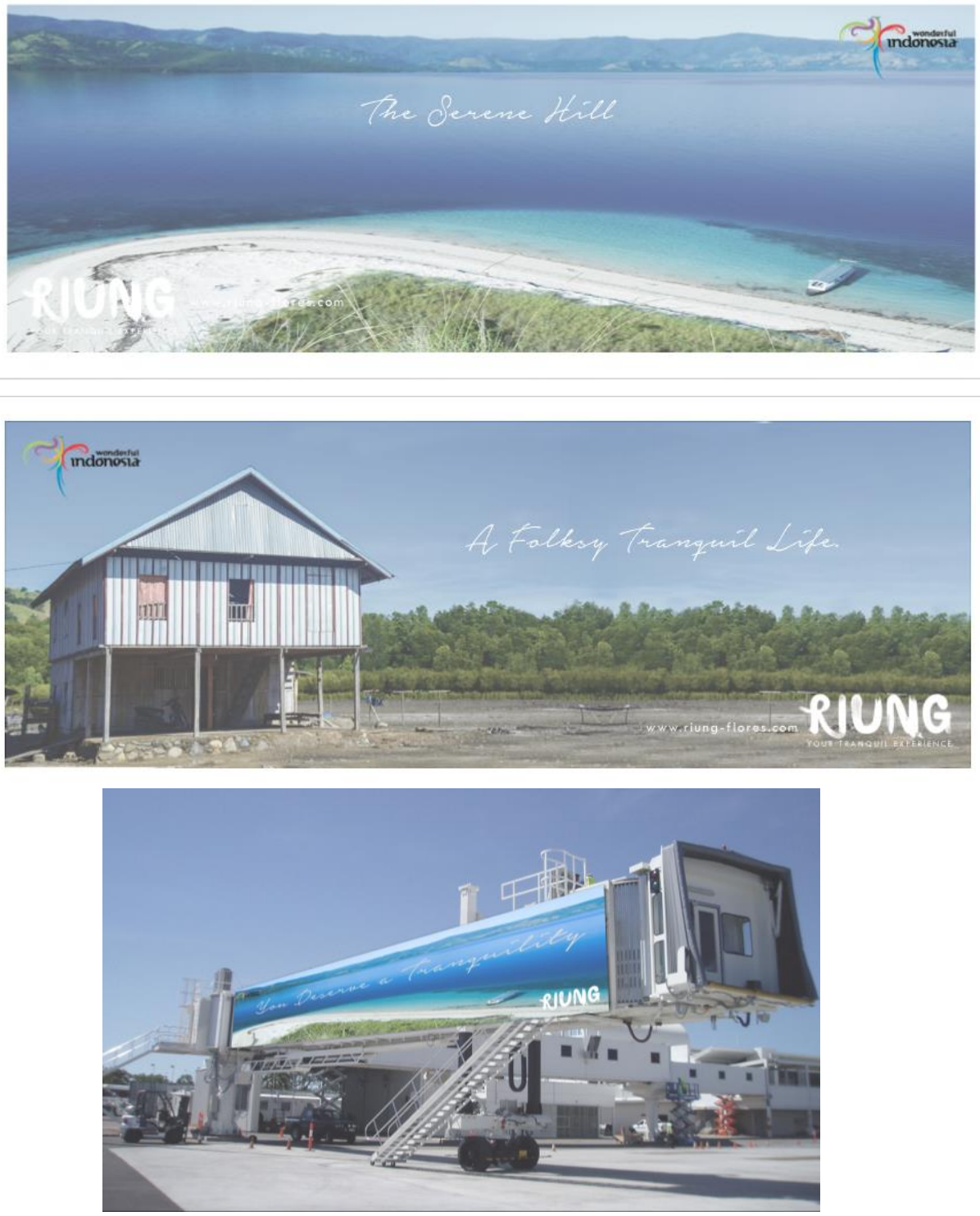

Gambar 5. Tampilan billboard 


\section{- Print Ad}
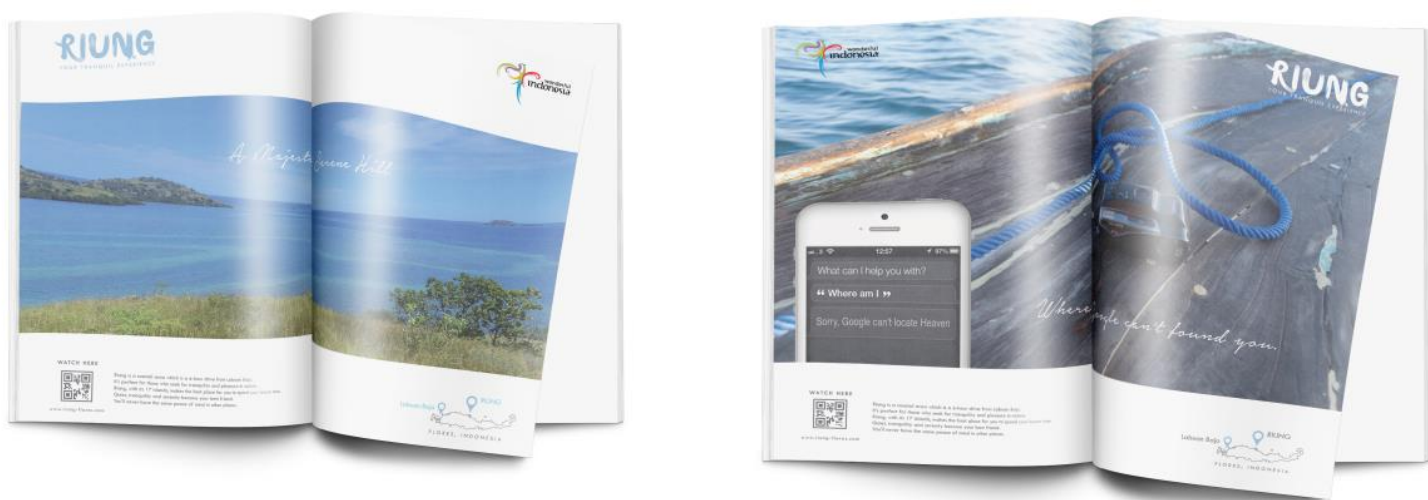

Gambar 6. Tampilan print ad

\section{- Ambience}

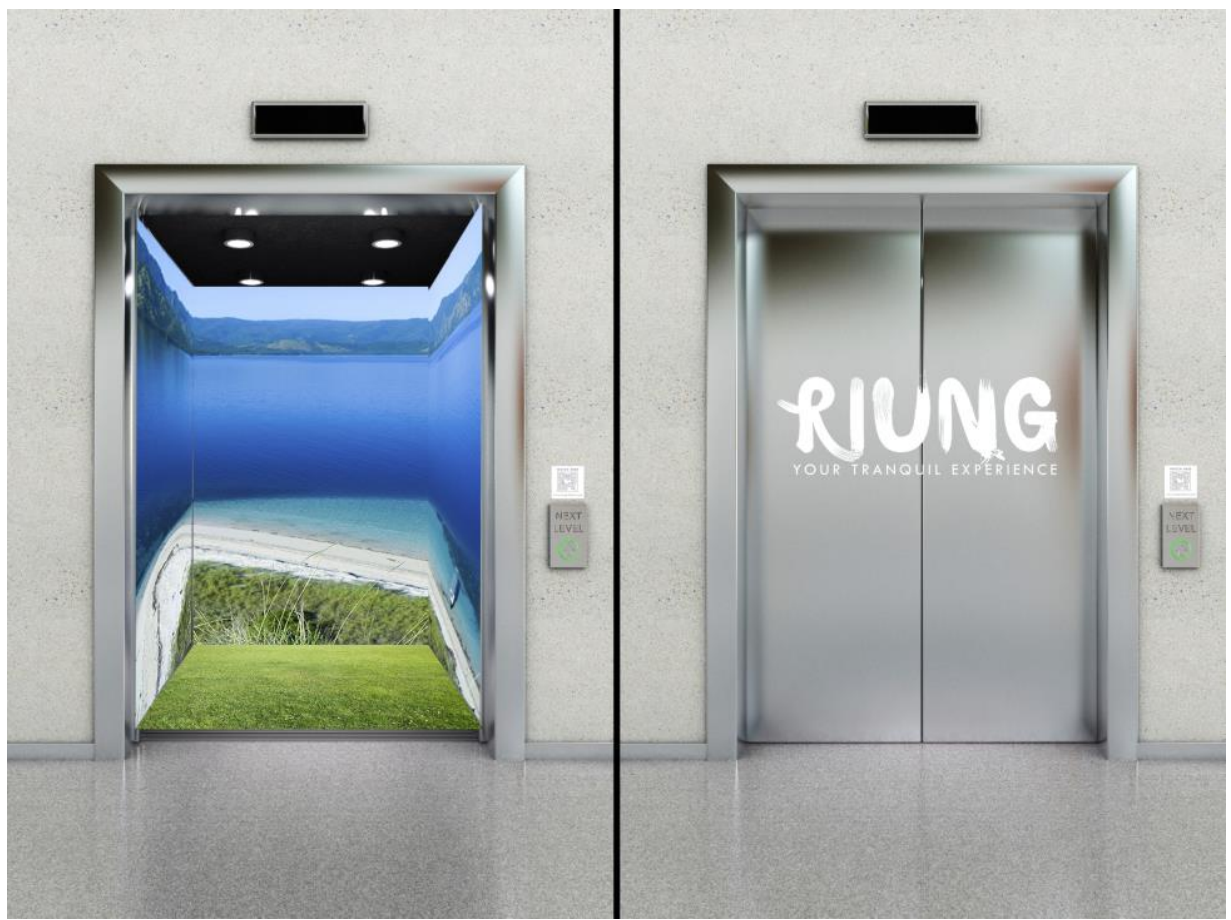

Gambar 7. Tampilan ambience 
- Travel Fair Uniform
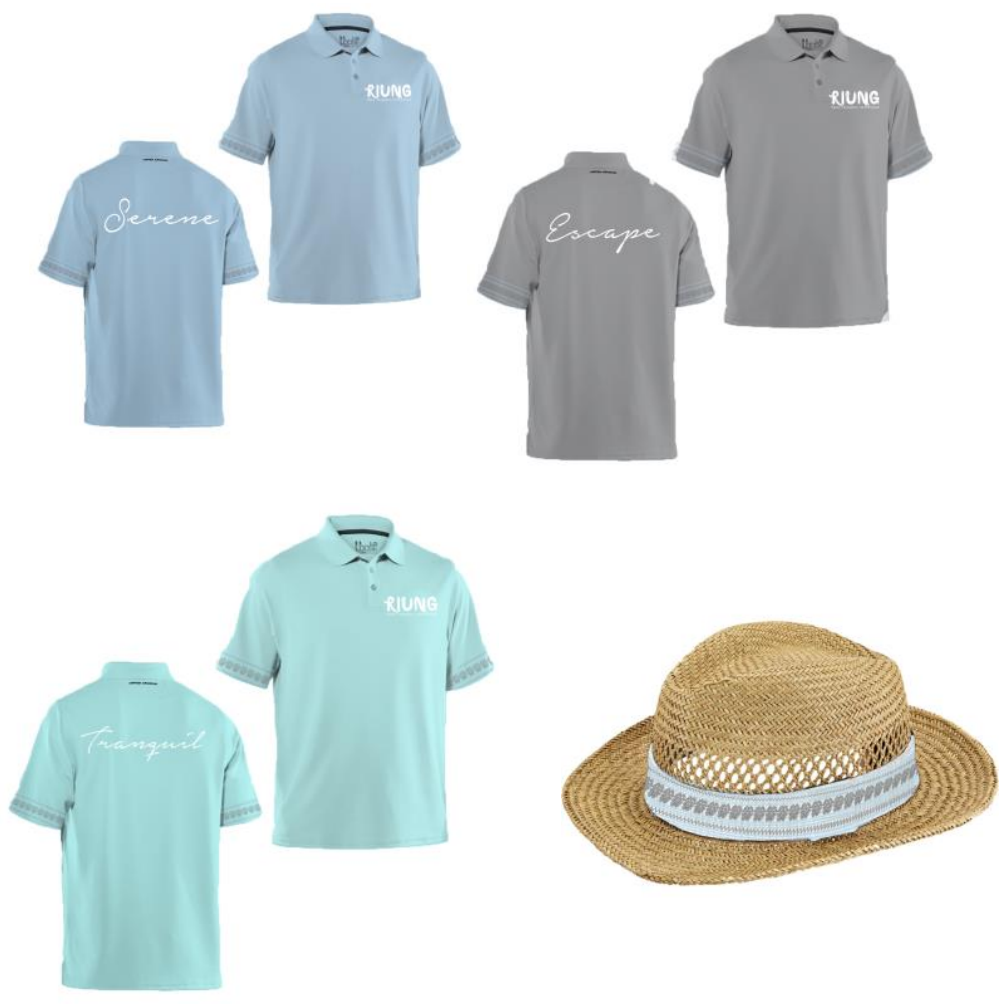

Gambar 8. Tampilan travel fair uniform

\section{- Souvenir}
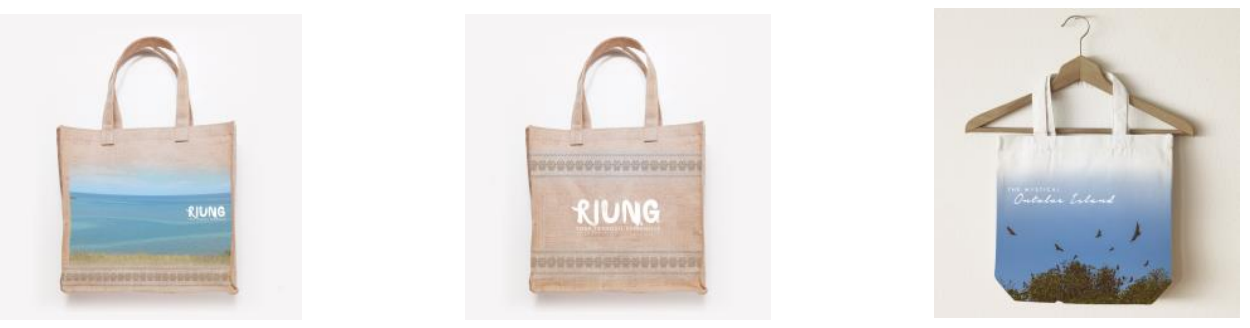

Gambar 9. Tampilan souvenir

\section{KESIMPULAN}

Dari penelitian di atas, dapat disimpulkan bahwa perancangan strategi komunikasi untuk kawasan wisata Riung terhadap wisatawan asing tidak bisa dengan mengandalkan konvensional media sebagai media utama, melainkan menggunakan digital melalui website. Media konvensional dibutuhkan sebagai reminder media utama. Media konvensional yang dibutuhkan pun ditempatkan di posisi yang strategis dan memiliki hubungan erat dengan psikologi dan kebiasaan pola hidup dari target komunikasi yang suka bepergian, semisal dengan menempatkan 
print ad pada majalah travelling atau in flight magazine. Penggunaan fasilitas-fasilitas di bandara sebagai media komunikasi, semisal garbarata juga digunakan sebagai reminder dan bersifat persuasif yang memberikan pengaruh secara psikologis terhadap target komunikasi.

Pemilihan media digital sebagai media utama karena adanya keterbatasan jarak antara kawasan wisata Riung dan juga target marketnya. Sehingga melalui satu media, yakni website, segala informasi dapat langsung tersampaikan. Website juga berfungsi sebagai media reservasi yang memudahkan target komunikasi bergeser menjadi target market.

\section{DAFTAR PUSTAKA}

Rustan, Surianto. (2008). LAYOUT, Dasar \& Penerapannya. Jakarta: PT. Gramedia Pustaka Utama.

Samara, Timothy. (2007). Design Elements, A Graphic Style Manual. USA: Rockport Publishers.

Sutton, Tina and Bride M.Whelan. (2008). The Complete Color Harmony. Singapore: Page One Publishing Private Limited.

Grappa, Carol Di. (2009). Landscape Theory. USA: Lustrum Press Publishers.

Jeffrey, Ian. (2009). How to Read a Photograph: Lessons from Master Photographers. USA: Abrams Publishers.

Pike, Steven. (2008). Destination Marketing: An Integrated Marketing Communication Approach. USA: Butterworth-Heinemann Publishers.

Baker, Bill. (2007). Destination Branding for Small Cities. USA: Butterworth-Heinemann Publishers.

Honey, Martha. (1998). Ecotourism and Sustainable Development: Who Owns Paradise?. USA: Island Press Publishers. 